\title{
Effect of Indoor Environmental Quality on Visual Comfort and Productivity in Office Buildings
}

\section{Abstract}

Visual environment is one of the most important indoor environmental quality parameters and directly impacts occupant productivity in offices. The literature outlines the significance of the impact. Still, there is a lack of investigation, statistical analysis, and inter-relationships between the independent variables (indoor environmental quality factors), especially in the hot and arid climate. This study presents a research study investigating the effects and shows statistical relationships between indoor environmental quality on occupant comfort and productivity. The study was conducted in the Middle East, and data were collected for 12 months. It used the Response Surface Analysis to perform analysis. It outlined seven unique relationships highlighting the recommended range, inter-dependencies. Results include that illumination has maximum effect on visual comfort and temperature, daylight having direct influence and relative humidity, wall type next to the seat and kind of workspace also have an impact on visual comfort and productivity. These findings would help to improve occupant comfort and productivity in office buildings. It is recommended to include results and recommendations on design guidelines for office buildings. This paper presents the unique effects of non-visual indoor environmental quality parameters on visual comfort and productivity. This investigation also provides a unique method to develop the statistical relationship between various indoor environmental factors and productivity in different contexts and buildings.

Keyword: Indoor Environmental Quality, Visual Comfort, Office Building, Response Surface Analysis

\section{Article Classification: Original Research Paper}

\section{Introduction}

People spend most of their hours indoors based on their job requirement, season, and age (Al-Esia and Skok, 2015; ASHRAE, 1993; Hailu, Gelan and Girma, 2021). Most of the urban population work in an indoor working environment (Bluyssen et al., 1996). An efficient and healthy working environment is essential and fundamental for all the occupants to work efficiently and productively (Mawson, 2002; Bueno, de Paula Xavier, Antonio Augusto and Broday, 2021). Indoor environment quality substantially affects occupant comfort and productivity (Humphreys, 2005; Abbaszadeh et al., 2006; 
Hassanain, 2007; Geng et al., 2017). Physical indoor environment quality consists of thermal comfort, indoor air quality, visual comfort, and audio comfort of the indoor space (Fisk, W. J. et al., 1999; Djongyang, Tchinda and Njomo, 2010; Peretti and Schiavon, 2011; Kaushik et al., 2020). All these I.E.Q. factors and comfort contribute to the overall comfort of the occupant and, thus, productivity (Figure - 1) (Fisk, William J., 2000b; Nicol and Humphreys, 2002).

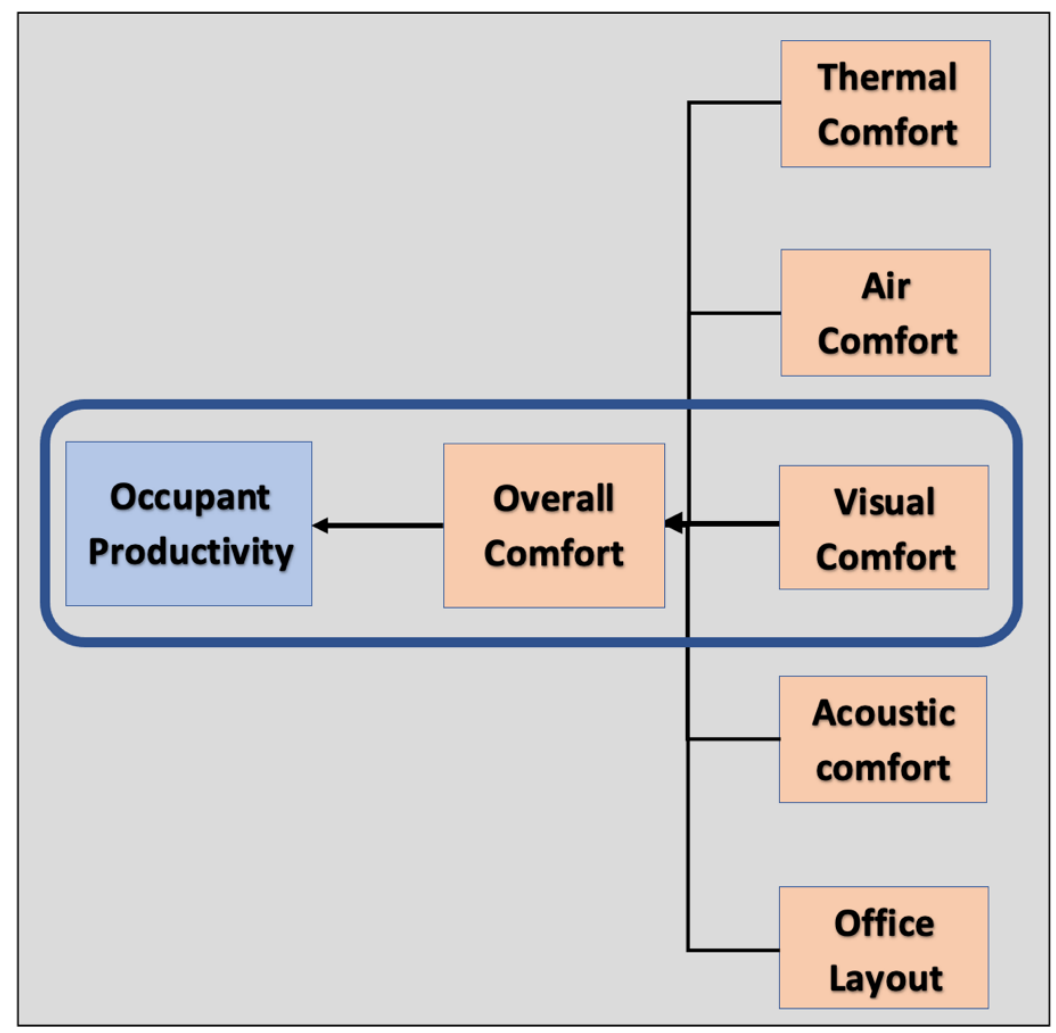

Figure 1 - Comfort and Productivity

Comfort is a prerequisite for productivity, but comfort doesn't always lead to productivity. Most building guidelines focus on comfort and but don't explicitly aim for productivity. Studies show that thermal and indoor air comfort has the highest share of impact on occupant comfort and productivity (Kaushik et al., 2020; Lin and Deng, 2008; Mujan et al., 2019). Nonetheless, visual comfort or lighting levels also directly influence occupant health and significantly impact indoor occupant comfort and productivity (Yun et al., 2012; Li and Tsang, 2008; Gou, Lau and Ye, 2014). Visual comfort is a fundamental need for office employees to perform their tasks efficiently and have good health. Efficient indoor environmental and productive occupants can substantially affect an organisation's financial performance (Fisk, William J., 2011; Fisk, William J., 2000a; Fisk, 2000). Numerous studies have highlighted the direct impact of quantity 
and quality of light on human health (Boyce, Peter R., 1997; Osibona, Solomon and Fecht, 2021). It is crucial to investigate the effect of visual comfort on occupant comfort and productivity.

This study aimed to underline the statistical relationship between lighting level and occupant comfort and productivity. It also focused on identifying any direct or indirect relationship non-visual parameters on visual comfort and product. The study was conducted by collecting physical parameters of an indoor environment in an office in a subtropical desert climate. The data was analysed using Response Surface Methodology to define the relationships.

The rest of the paper is divided into five sections. The following section presents a literature review on lighting and daylighting and a discussion on indoor lighting measurements. The second section offers the design of the experiment. It highlights the research structure, including the survey design, data collection strategy and data analysis. The third section presents the study results, including Analysis of Variance (ANOVA), Regression Analysis, relationship equation and graphs. The fourth section discusses the results and their implications for building design. The last section presents the conclusion of the study.

\section{Lighting and Daylighting (Visual Comfort)}

Visual comfort influences occupant comfort and satisfaction within an indoor environment (Frontczak and Wargocki, 2011). Visual comfort depends on the nature and level of lighting - both daylight and artificial light. Daylight influences our biological clock. It is set for millions of years based on the sun's movement (sunrise and sunset). It controls our physiology and productivity (Aries, 2005; Giarma, Tsikaloudaki and Aravantinos, 2017). Daylight is advised to be the best source of light with excellent colour for human health and comfort. It positively influences occupant mood, performance, and mental attitude (Li and Lam, 2001; Beute and de Kort, 2018). As office employees spend most of their time indoors (Bernstein et al., 2008), office environments depend much on artificial lighting due to numerous circumstances like building design, orientation, and sunlight availability due to clouds or windows. Due to this dependency on artificial light, buildings worldwide use about $40 \%$ of the world's annual usage of electricity (Omer, 2008). In the U.K., research suggests that lighting has the most significant share (33\%) in total average utilisation of electricity (CIBSE, 2015)(See Figure ). 
In the U.S. (2002 data), around US\$40 billion per year is spent on electricity for lighting. About one-third of this expenditure is spent on lighting consumption by American workers, taking US\$5.3 trillion in salaries and producing goods and services worth US\$9.2 trillion (Steffy, 2002). Indoor lighting has a one-third share in global office electricity consumption. These facts make it one of the significant contributors to global carbon emissions.

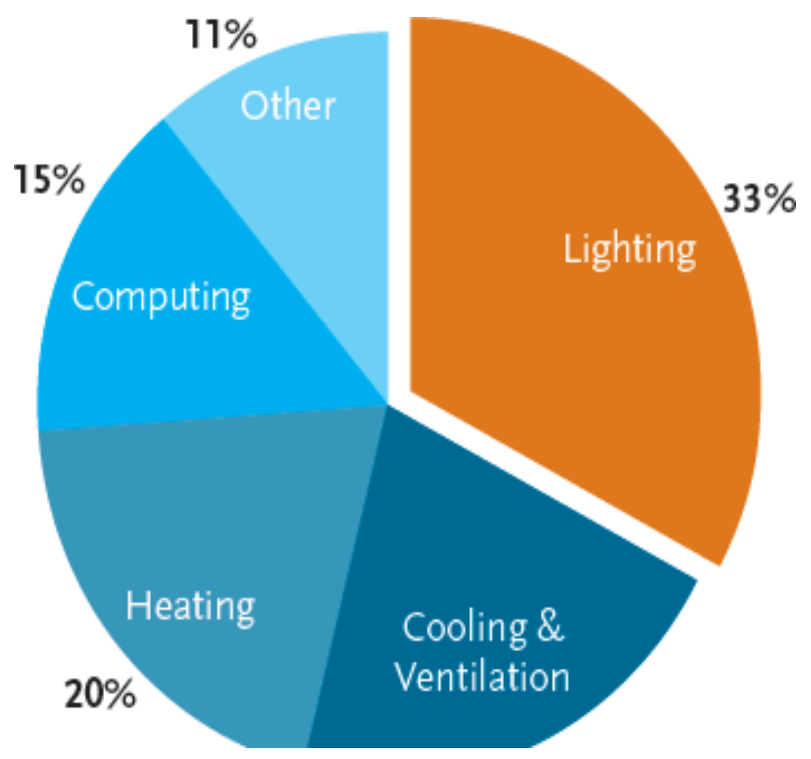

Figure 2 - Electricity usage (U.K.) (CIBSE, 2015)

Research suggests that companies gain long-term profit by higher occupant productivity and lower electricity cost by investing in daylight inclusivity in the workplace design (Lim et al., 2012; Turan et al., 2020; Carletti et al., 2017). Daylight inclusion in workplace design has led to increased attendance and a decrease in occupant complaints in offices (Romm and Browning, 1994; Knoop et al., 2020). Humans prefer natural light when red to artificial light (Elzeyadi, 2011; Kong et al., 2018). Preference can be divided into three categories: psychological, physiological, and physical. Artificial lighting covers a wide range of the colour spectrum that includes the range of sunlight and daylight. The main reasons are psychological and physiological factors. Human performance is highly dependent on parameters such as luminance contrast, retinal illumination, retinal image quality and visual size (de Vries et al., 2018). The visual and circadian system is influenced by natural light (Rea, M. S., Figueiro and Bullough, 2002). It also affects the melatonin hormone, which regulates the body's clock that maintains the body's sleep and alertness pattern in contributes to maintaining alertness and focus during office hours (Nagy, Yasunaga and Kose, 1995). Both 
daylight and natural light refer to the light provided by direct or indirect presence due to sunlight.

There are many ways to incorporate daylighting into workplace design. One of the widely used is to include windows to maximise daylight in the workspace. Occupants also prefer workplaces with windows and report that they help improve the office tasks' productivity(Cuttle, 1983; Lottrup et al., 2015). Outside views of surrounding green areas and nature also lead to a positive impact on occupant productivity (Cuttle, 1983; Lottrup et al., 2015; Bright, 2012; Grinde and Patil, 2009; Kent and Schiavon, 2020). There is evidence of occupants' preference for natural light and windows. However, various factors need to be accounted for while designing windows for the workplace. Excessive daylight or other light causes' glare'. It leads to strain in the eye and temporarily reduces the subject's visual capability (human) experiencing it (Słomiński and Krupiński, 2018). These factors include outdoor lighting levels, required indoor lighting levels, outside sky illuminance and the position of the sun (Ne'Eman and Hopkinson, 1970; Mansfield, 2018). Occupant surveys also indicate that universally, they prefer access to sunlight; the windows' desired size and locations may vary depending on the light requirement, size, layout, and position of the desk (Butler and Biner, 1989; Wotton, 1982). In high-rise buildings, providing large windows on the south side (low sun path) leads to higher usage of blinds than on the north side of the building (Rubin, Collins and Tibbott, 1978). In summary, occupants prefer daylight at the workplace; however, window size and location should be determined based on various factors like lighting requirement of the space, layout and orientation of the building, location, and daylight availability.

Daylighting design is a method to incorporate daylight into the lighting design of a space. It looked at the daylight availability and required light levels using different elements, such as a window, skylight, and reflector glasses (Guzowski, 2000; Manning, 2006; Kittler et al., 1992; Caicedo and Pandharipande, 2016). Illuminance from natural sources is calculated by the Daylight Factor (D.F.). It represents the percentage of daylight in the overall lighting of the space (measured at overcast conditions), which is based on three factors: Sky Component (S.C.), External Reflected Component (ERC) and Internal Reflected Component (I.R.C.) (Wong et al., 2017; Hopkinson, Petherbridge and Longmore, 1966; Fontoynont, 2014). The literature recommends $1.5-2.5 \%$ D.F. for regular tasks like filling work, general reading, and meetings. Tasks 
that require reading, writing, and machine work for long hours need $2.5 \%-4 \%$ D.F. Mentally straining, challenging tasks that require high focus and attention to detail, such as draughting, fine hand or machine work, writing reports, and document inspection needs 4\% - 8\% D.F. (Stein, Reynolds and McGuinness, 1992; Reinhart, Mardaljevic and Rogers, 2006). These percentages represent the preferred factor of daylight in the overall illuminance (Lux) of the space. Designers need to be mindful while designing the general illuminance of the space. A higher level of illuminance levels leads to glare that results in visual discomfort.

Similarly, lower illuminance levels also lead to melatonin hormone secretion that affects alertness, performance, and visual discomfort. Illuminance is the total light's incidence on a surface, measured as Lux (Ix) (David L.. DiLaura et al., 2011; Hamedani et al., 2019). Visual discomfort leads to lower productivity and wellbeing (Van Den Wymelenberg and Inanici, 2014). Maintaining conducive illuminance levels for a healthy and productive workspace is necessary. Different types of tasks require different illuminance levels. For regular office work such as file work, general reading and meetings, the minimum required is 100 Lux, while the recommended average is 200 Lux. For office work that requires detailed work such as report writing and reading, 200 - 300 Lux range is recommended. For detailed work for a long time, such as draughting, delicate hand or machine work, the recommended range is 200-500 Lux (Rea, Mark Stanley, 2000).

Based on the above literature review, we can conclude that the lighting design of a workplace should use indoor (artificial) lighting and daylight to create a conducive lighting environment for the occupants. It should look at contextual factors such as:

1. Light requirements based on tasks and working hours

2. Location, orientation, and height of the workplace

3. Occupant requirement and preference

4. Availability of daylight

Along with the above factors, designers should aim to reduce the lighting energy consumption by using various daylighting strategies (Chang and Mahdavi, 2002; Doulos, Tsangrassoulis and Topalis, 2005). Managing light systems by using different light sensors and relays can help to reduce electricity consumption. This system can be used in two ways: 
- Maximising daylight usage: A building's electricity usage can be reduced using operational façade elements to utilise daylight in the building efficiently. It involves using sensors to automatically open and close the façade elements by measuring and sensing the outdoor illuminance concerning required indoor illuminance.

- Reducing artificial light usage: Building's electricity usage can be reduced using various movement/occupancy sensors to switch off when occupants leave the building.

The literature review of lighting and daylighting has outlined the fundamentals of lighting, its importance in improving occupant productivity and ideal range based on industry standards. It also outlined various ways to incorporate daylighting into the lighting design of a workspace.

The lighting of a workplace should be designed using several factors. These include lighting, colour and contrast levels that are comfortable for the human eye. Lighting design should also consider the specific lux level requirements for different types of tasks. A combination of lighting systems should be designed that uses both artificial and daylighting to create a sustainable and efficient approach that provides a conducive lighting environment to improve occupant comfort and productivity.

This research focuses on measuring illuminance levels (Lux), daylight access and their influence on occupant comfort and productivity (Table - 1).

\begin{tabular}{|c|c|c|}
\hline \multicolumn{3}{|c|}{ Lighting and Daylighting } \\
\hline $\begin{array}{l}\text { Measurable } \\
\text { parameters }\end{array}$ & Instrument & Occupant Survey \\
\hline $\begin{array}{c}\text { Illuminance level } \\
\text { (Ambient) }\end{array}$ & Lighting Sensor & \\
\hline Daylight access & $\begin{array}{ll} & \text { Location of the occupant } \\
\text { - } & \text { Exterior wall } \\
\text { - } & \text { Interior wall } \\
\text { - } & \text { Exterior window } \\
\text { - } & \text { Interior window } \\
\end{array}$ & $\begin{array}{l}\text { response to indoor } \\
\text { lighting }\end{array}$ \\
\hline
\end{tabular}

Table - 1 - Lighting and Daylighting - Parameters and Instrument 


\section{Experiment Design}

The primary drivers of designing the indoor environment should be based on its contextual climate conditions, the building's layout and orientation, and material and occupant behaviour. Field studies reviewed recommend that Post Occupancy Evaluation (P.O.E.) is an effective way to measure the effect of indoor environmental quality factors on occupant comfort and productivity (Göçer, Hua and Göçer, 2015; Collinge et al., 2014; Hua, Oswald and Yang, 2011; Hirning et al., 2013; Gou and Lau, 2013). This research study used P.O.E. to collect occupants' responses and deployed sensors for physical measurement of Temperature and relative humidity. The experiment was conducted in an office located in the Middle East. The context has a subtropical desert climate. It faces an arid, hot, and humid summer with low annual rainfall. Local weather forces habitants to most of their time indoors. It has also led to the development of enveloped buildings to control the indoor environment and provide comfort and wellbeing to the occupants. It acts as an opportunity to investigate this topic in given climatic conditions. People spending most time indoors in a controlled indoor environment meant that the office serves as the most effective working laboratory for the experiment. A medium-sized office with 40 employees was used for the investigation. It was divided into 12 zones, and sensors were installed accordingly (Figure - 2). The data was analysed using Response Surface Methodology in MiniTab. The regression equation's outcomes determine the mathematical relationship between independent (indoor parameters) and dependent (occupant productivity) variables. It also produced an R-square value that determines the degree of association between independent and dependent variables and contour and surface plots that present the multinomial relationship between occupant productivity and various indoor environmental parameters. 


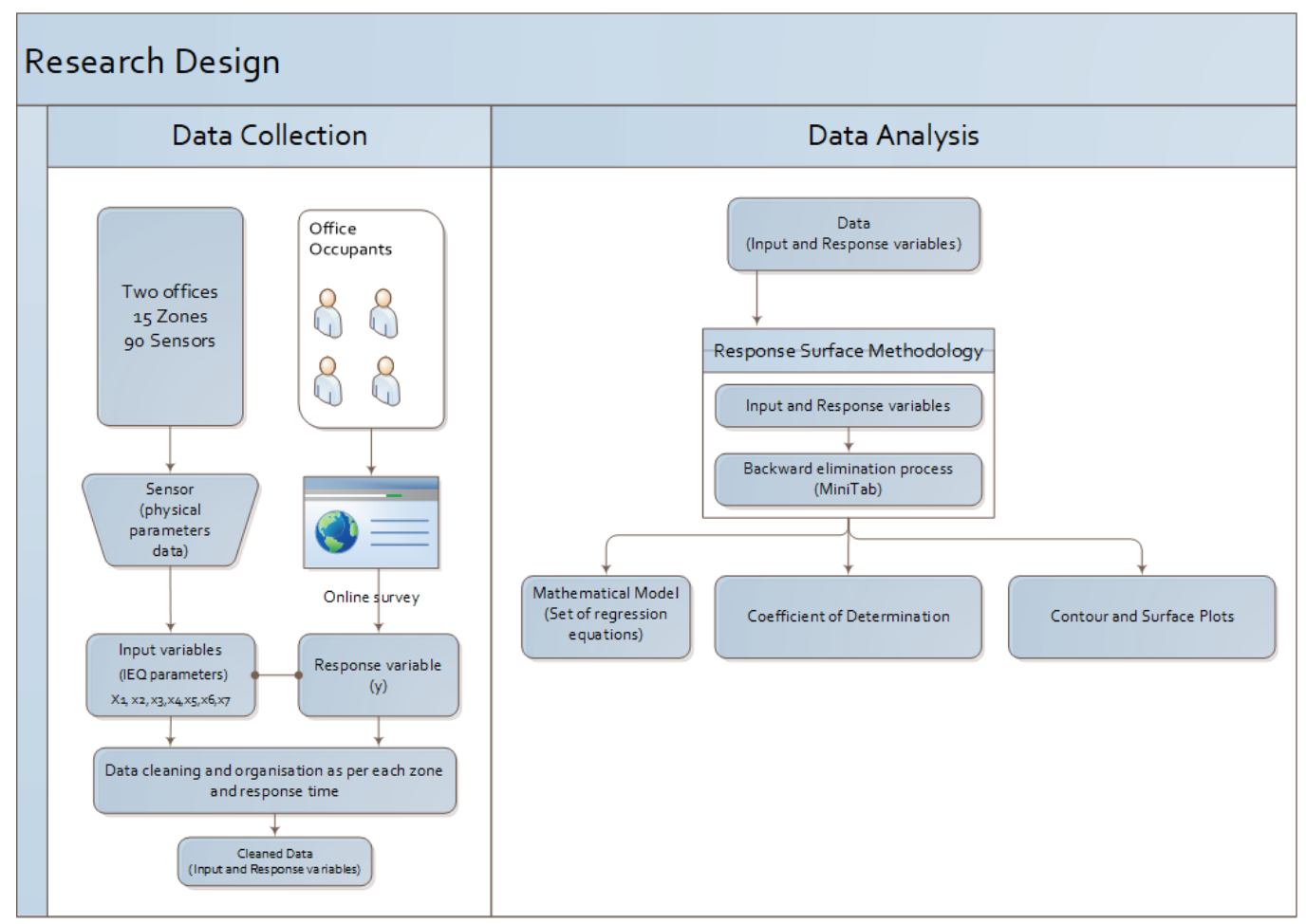

Figure - 3 - Research Design

\subsection{Occupant Survey}

The study involved sending an online survey to occupants every fortnight by the organisation's Human Resource department. Data was collected and stored safely, and employee profiles were managed using data encryption and were kept anonymous. The replies were time-stamped along with their zone. The research team created a questionnaire (Table - 2) for occupants to fill online. The study also focused on other indoor environmental quality factors and collected physical data and occupant response. This paper concentrates only on visual comfort and outlines any interactions of different environmental parameters on visual comfort. The study uses an occupant survey on self-reported productivity, and there are certain reservations about such surveys in the literature (Göçer et al., 2019; Lipczynska, Schiavon and Graham, 2018). Due to this, the question was focused on the effects of the indoor environment on productivity rather than employees' productivity levels. This also aligns with the study's aim to outline the effect of the indoor environment on productivity rather than the measure of productivity. The survey asked occupants to respond to illumination levels and how it was affecting their productivity. The response options were very negative, negative, neutral, positive, and very positive, based on the Likert scale (Allen and Seaman, 2007). Each response was time-stamped along with the zone to ensure 
that every measurement was accurately calculated (average of a past hour). Each response was mapped against the physical parameters measured, such as temperature, relative humidity, lux levels, carbon dioxide, and sound. Survey response was time-stamped. Hence, they can be correlated with the sensor data for each data point. In the response surface methodology term, these data points can also be termed as runs. The runs would enable us to calculate and generate several relationship equations between seven input variables and the performance variable(y).

\section{Question - How have these factors affected your productivity?}

\begin{tabular}{|l|l|l|l|l|l|l|}
\hline & $\begin{array}{l}\text { Indoor environ- } \\
\text { ment factor }\end{array}$ & $\begin{array}{l}\text { Very Nega- } \\
\text { tively }\end{array}$ & Negatively & Neutral & Positively & $\begin{array}{l}\text { Very Posi- } \\
\text { tively }\end{array}$ \\
\hline A & Thermal comfort & & & & & \\
\hline B & Natural ventilation & & & & & \\
\hline C & $\begin{array}{l}\text { Mechanical } \\
\text { ventilation }\end{array}$ & & & & \\
\hline D & $\begin{array}{l}\text { Low emitting } \\
\text { materials }\end{array}$ & & & & & \\
\hline E & Illumination levels & & & & & \\
\hline F & Daylight & & & & \\
\hline G & $\begin{array}{l}\text { Dndoor chemical \& } \\
\text { pollutant source } \\
\text { control }\end{array}$ & & & & & \\
\hline H & Acoustic quality & & & & & \\
\hline I & Office layout & & & & & \\
\hline
\end{tabular}

\subsection{Physical Parameters Measurement}

The physical environment data were collected using sensors in each zone. The experiment used factory calibrated sensors for all the environmental parameters. Literature also outlined that outdoor Temperature and relative humidity indirectly impact occupant comfort and productivity inside mechanically ventilated buildings (Humphreys, 2005; Humphreys and Nicol, 2000). Hence, outdoor temperature and relative humidity sensors were also installed to map any outdoor thermal environment's effect on occupant comfort and productivity. All the sensors were connected to a base unit (B.R.E. base unit) which uploaded the data to an online repository that allowed downloading the data in the excel file. All the sensors were monitored to ensure that they were 
working efficiently. Office Layout data was collected from the seating position of the employees. There were five types of workspaces: individual room, shared cubicle, cubicle and open plan, and shared open plan. There were three options for window type: exterior window, interior window, and no window. This data was collected from the Human Resource Department and layout plan. Participants' names were removed, and identities were kept anonymous.

\begin{tabular}{|c|c|c|c|c|}
\hline $\begin{array}{l}\text { I.E.Q. } \\
\text { factor }\end{array}$ & Parameter & Measured by & $\begin{array}{c}\text { Input } \\
\text { Variable }\end{array}$ & $\begin{array}{l}\text { Response/ per- } \\
\text { formance varia- } \\
\text { ble }\end{array}$ \\
\hline \multirow{4}{*}{$\begin{array}{l}\text { Thermal } \\
\text { comfort }\end{array}$} & Temperature & \multirow{2}{*}{$\begin{array}{l}\text { Zigbee T- } \\
\text { 3524C }\end{array}$} & $x_{1}$ & \multirow{9}{*}{$\begin{array}{c}\text { che } \\
\qquad y \\
\text { (calculated from } \\
\text { the survey re- } \\
\text { sponses) }\end{array}$} \\
\hline & Relative humidity & & $x_{2}$ & \\
\hline & $\begin{array}{l}\text { Outside Tempera- } \\
\text { ture }\end{array}$ & \multirow[t]{2}{*}{ Vantage Pro } & $x_{3}$ & \\
\hline & Outside R.H. & & $x_{4}$ & \\
\hline \multirow{2}{*}{$\begin{array}{l}\text { Indoor Air } \\
\text { Quality }\end{array}$} & Carbon dioxide & $\begin{array}{l}\text { Zigbee T- } \\
3571\end{array}$ & $x_{5}$ & \\
\hline & $\begin{array}{l}\text { Volatile Organic } \\
\text { Compound }\end{array}$ & \multirow{2}{*}{$\begin{array}{l}\text { Zigbee T- } \\
\quad 3576\end{array}$} & $x_{6}$ & \\
\hline Lighting & Lux level & & $x_{7}$ & \\
\hline Noise & Sound level & $\begin{array}{l}\text { Zigbee T- } \\
3551\end{array}$ & $x_{8}$ & \\
\hline $\begin{array}{l}\text { Office Lay- } \\
\text { out }\end{array}$ & $\begin{array}{c}\text { Seating Arrange- } \\
\text { ment }\end{array}$ & $\begin{array}{l}\text { Researcher } \\
\text { (Office plan) }\end{array}$ & $x_{9}$ & \\
\hline
\end{tabular}

\subsection{Data Analysis: Response Surface Methodology}

This research study used the Response Surface Methodology (R.S.M.) for data analysis. It provides a framework for analysing Indoor Environmental Quality. Parameter data and occupant survey data to develop various statistical relationship models that outline the degree of influence of each I.E.Q. Factor on occupant productivity. R.S.M. is a collection of statistical and mathematical techniques used to develop and interpret polynomial equations (Box and Draper, 1987; Myers, Montgomery and Anderson- 
Cook, 2016). The main aim of the R.S.M. model is to investigate independent variables, test empirical models for developing an appropriate relationship between the response and the input variables and optimise methods for estimating values of $x_{1}$, $\mathrm{X} 2, \ldots, \mathrm{Xk}$ that produce the most desirable value of y (Ximénez and San Martín, 2000; Hill and Hunter, 1966; Alizadeh and Sadrameli, 2019).

$f=y=f\left(x_{1}, x_{2}, \ldots ., x_{k}\right)+\varepsilon$

$y=$ response/ performance variable

$x=$ input variables

$\varepsilon=$ noise or error observed in the response $y$

The surface represented by $f\left(x_{2}, \ldots, x_{k}\right)$ is called the response surface. It can be represented graphically (three-dimensional space or as contour plots) to understand the shape of the response surface. This analysis used R.S.M. to generate the relationship between nine parameters (under five indoor environmental factors) and occupant response (Survey).

The data was collected for twelve months and resulted in 500 survey data points. After the cleaning and adjustment, 368 data points were used to perform the analysis. The response surface analysis was conducted using Minitab software. The researcher used a backward elimination procedure to conduct response surface analysis. This process helps eliminate any input variable with a profound effect on the output variable in any multiple regression analysis. Backward elimination starts with all the input variables in the model and eliminates one input variable in each run with the least effect on the model. This stepwise procedure continues until the no input variables in the model have a p-value greater than the value specified (alpha to remove). In this case, researchers used 0.1 as alpha to remove the value in this experiment. It produces results with $90 \%$ confidence.

\section{Results: Response Surface Methodology}

Response surface analysis of visual comfort was carried out to identify the input variables that influence an occupant's perception of visual comfort and how it affects their productivity. This section is divided into three sections: ANOVA (Analysis of Variance), $\mathrm{R}$ square (Coefficient of Determination), Regression Equation, Response Surface Analysis. 


\subsection{Analysis of Variance (ANOVA)}

Analysis of Variance test is used to describe the relationship between independent and dependent variables (Tabachnick and Fidell, 2007; Kirk, 2012).

The experiment was based on the following hypothesis:

- $\mathrm{H}_{0}=$ Variable does not affect occupant's visual comfort and its impact on productivity.

- $\mathrm{H}_{\mathrm{alt}}=$ Variable influences occupant's visual comfort and its impact on productivity.

The ANOVA is done using $\alpha=0.1$.

If $p$-value $\geq 0.1$, it indicates strong evidence of null hypothesis.

If $p$-value $\leq 0.1$, it indicates strong evidence against the null hypothesis, hence rejecting the null hypothesis.

Based on the ANOVA, the following factors influence occupant visual comfort level and its impact on the productivity of occupants:

1. Illumination (Light)

2. Temperature

3. Relative Humidity

4. Sound

5. Kind of workspace

The above factors affect visual comfort both directly and indirectly. All these factors have a different magnitude of influence.

\subsection{Regression Analysis}

Regression analysis was also conducted as part of the response surface analysis. The coefficient of determination (adjusted R-square) value is $82.25 \%$. It indicates that the functional equation explains $82 \%$ of variations in the dependent variable, leaving only $18 \%$ of variations unexplained. It also produced a regression equation (corrected up to three decimal places). 


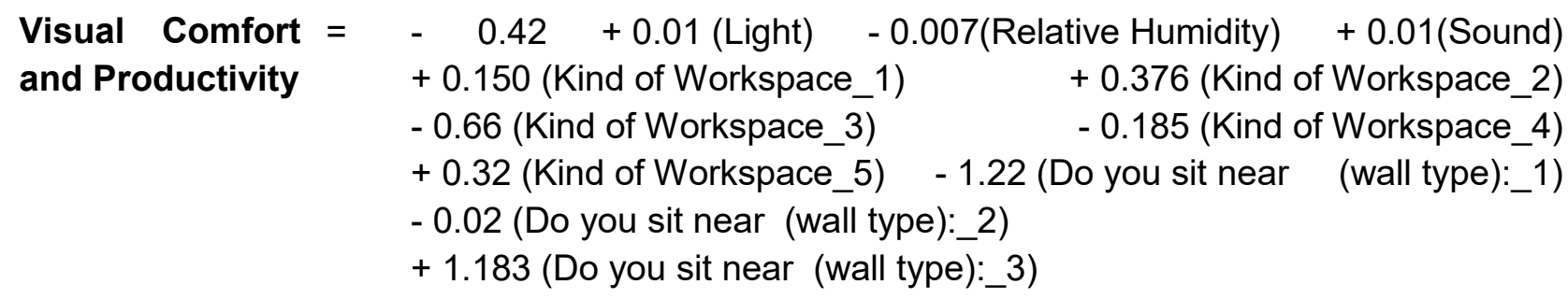

\section{Variables}

- $\quad$ Light $=$ Lux level

- Relative Humidity of the space

- $\quad$ Sound = dBA level

- Kind of workspace_1 = Individual room

- Kind of workspace_2 = Shared room (up to two occupants)

- Kind of workspace_3 = Cubicle

- Kind of workspace_4 = Open plan

- Kind of workspace_5 = Shared open-plan space

- Do you sit near (wall type) _ 1 = Exterior wall

- Do you sit near (wall type) _2 = Interior wall

- Do you sit near (wall type) _3 = Exterior window

- Do you sit near (wall type) _ $4=$ Interior window

The regression equation shows by how much each of the specified independent variable influence or affect the dependent variable, which in this case is the occupant's visual comfort and productivity. The equation provides some expected outcomes and some new implicit effects.

- Lux and Sound level - It demonstrates that lux and sound level has a subtle effect on visual comfort and productivity (0.01). It shows that an increase in lux level leads to improvement in visual comfort and productivity.

- Kind of workspace - It demonstrates that individual (+.150) and shared (up to two occupants) rooms $(+0.376)$ have a positive impact on visual comfort and productivity. Open plan (low-level partition) $(-0.185)$ and cubicle $(-0.66)$ have a negative impact, and interestingly, shared open-plan (open plan without lowlevel partition) $(+0.32)$ has a positive impact on productivity.

- Wall type - It demonstrates that no access to a window (wall type 1,2 ) has a negative impact on visual comfort and exterior window access has a significant impact on visual comfort and productivity. Window and natural light access and its relation to productivity are widely documented in the literature, and this study confirms the literature. It will also help to predict the variation in visual comfort and productivity. 
The equation analysis shows that access to natural light has a more substantial effect than overall lux levels. Individual and shared rooms are preferred over the cubicle and low height open plan.

\subsection{Response Surface Analysis}

Response Surface Analysis produced contour and surface plots. They are used to identify optimal results by showing the effect of two independent variables on the dependent variable. This section only highlights the plots that show substantial impacts or results on visual comfort and its effect on productivity.

\subsubsection{Effect of Temperature, Carbon Dioxide on Visual Comfort and Productivity}

Temperature and carbon dioxide influence visual comfort and their impact on productivity (Bueno, et. al., 2021). The temperature range between $20-27^{\circ} \mathrm{C}$ has a very positive influence on visual comfort. The carbon dioxide range has a very positive effect when 550 ppm and below. The plotlines in Figure 4 show that temperature has more influence on visual comfort than carbon dioxide. Carbon Dioxide has minimal impact, and the temperature has an indirect effect on visual comfort and productivity.

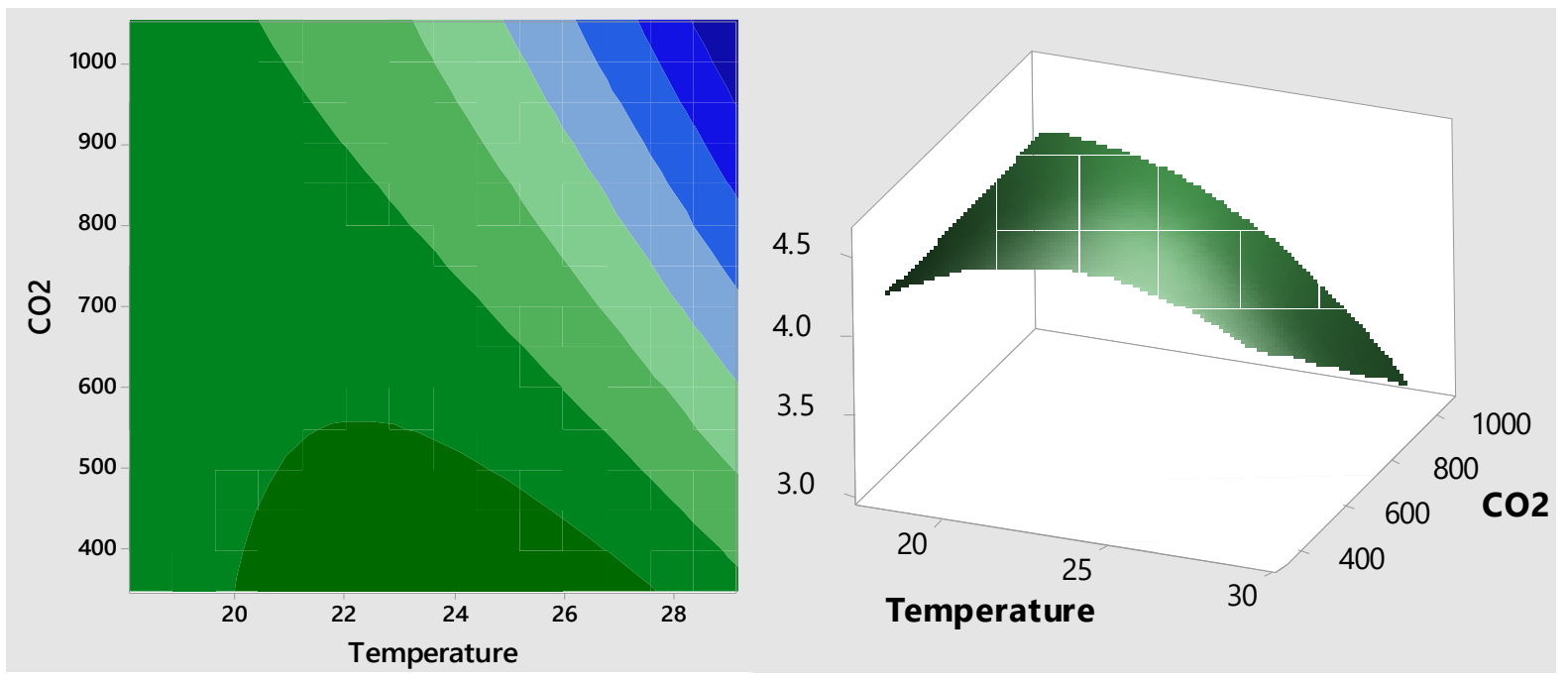

Figure 4 - Effect of Temperature, Carbon Dioxide on Visual Comfort

\subsubsection{Effect of V.O.C., Light on Visual Comfort and Productivity}

Contour and surface plots in figure -5 show that V.O.C. does not show any effect on visual comfort. Light levels have a significant impact on visual comfort. It confirms the ANOVA test findings that V.O.C. doesn't have any influence on visual comfort. The 
plot indicates that the lighting level has a significant impact on visual comfort. The optimum lighting levels are 350 - 450 Lux.

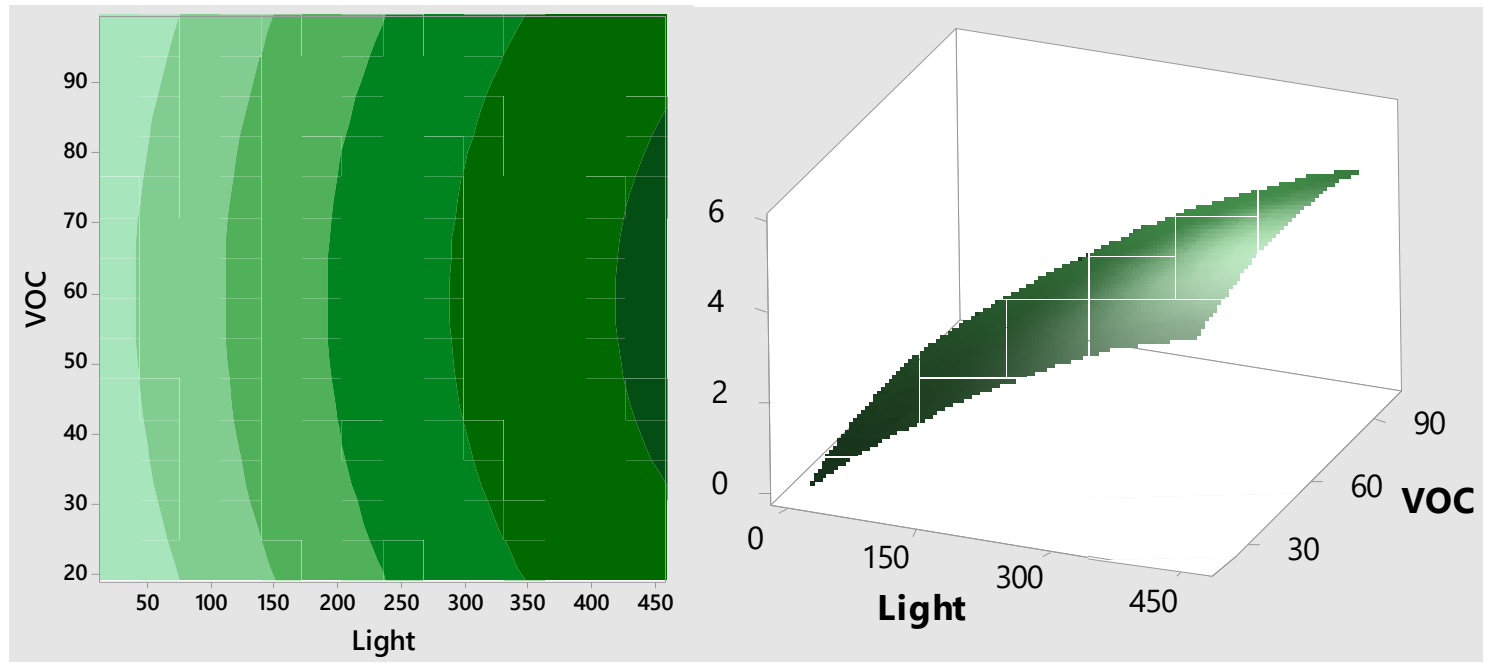

Figure 5 - Effect of V.O.C., Illumination on Visual Comfort

\subsubsection{Effect of Sound, Light on Visual Comfort and Productivity}

The plotlines in Figure 6 indicate that sound does not have a significant effect on visual comfort. ANOVA test shows that sound affects visual comfort and productivity. However, this relationship shows that sound does not affect visual comfort compared to illumination (light intensity). Illumination has a direct impact on visual comfort, and the optimum range is $325-450$ Lux.

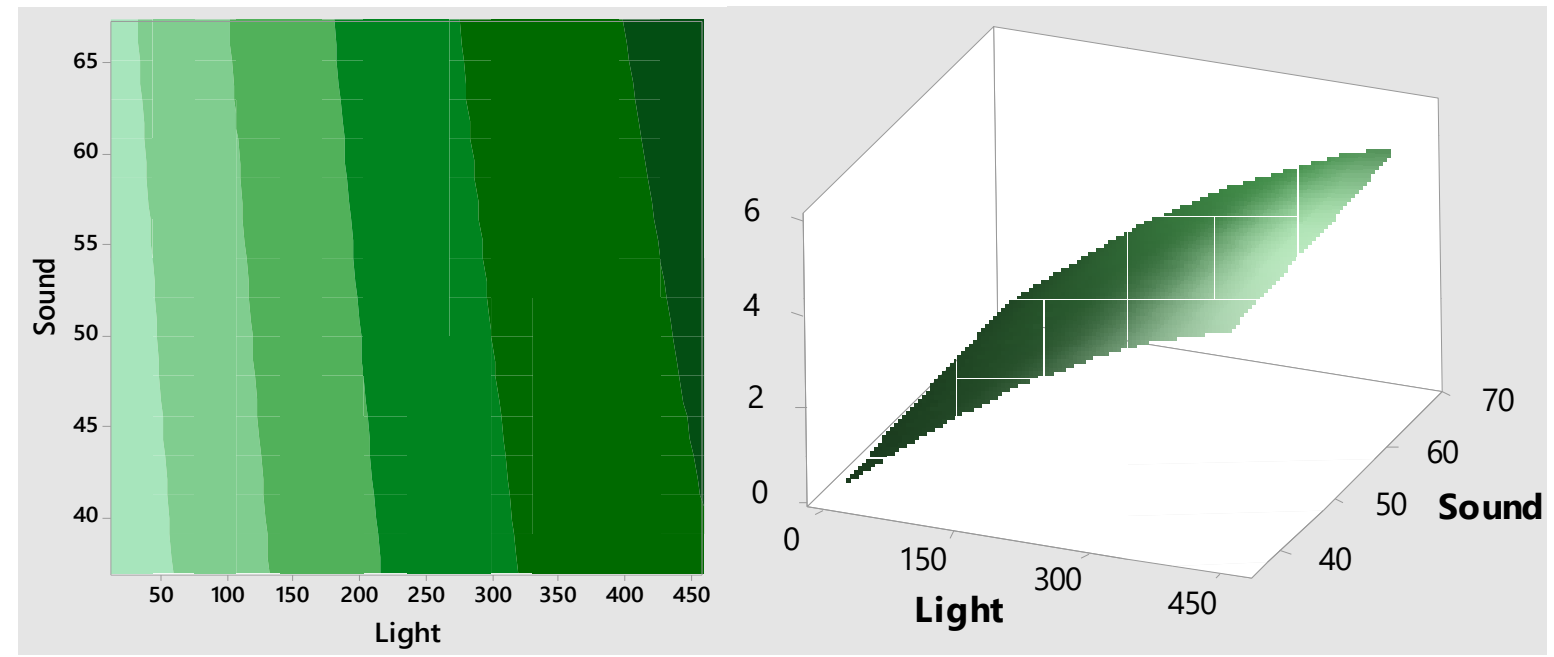

Figure 6 - Effect of Sound, Illumination on Visual Comfort 


\subsubsection{Effect of Outside Relative Humidity, Illumination (Light) on Vis- ual Comfort and Productivity}

Contour and surface plots in Figure 7 indicate that outside relative humidity does not significantly affect visual comfort. It confirms the finding of ANOVA results on outside relative humidity. Illumination levels directly affect visual comfort, and the optimum range is 275 - 450 Lux. It has a positive effect from 200 Lux, and it has a very positive impact from 275 Lux.

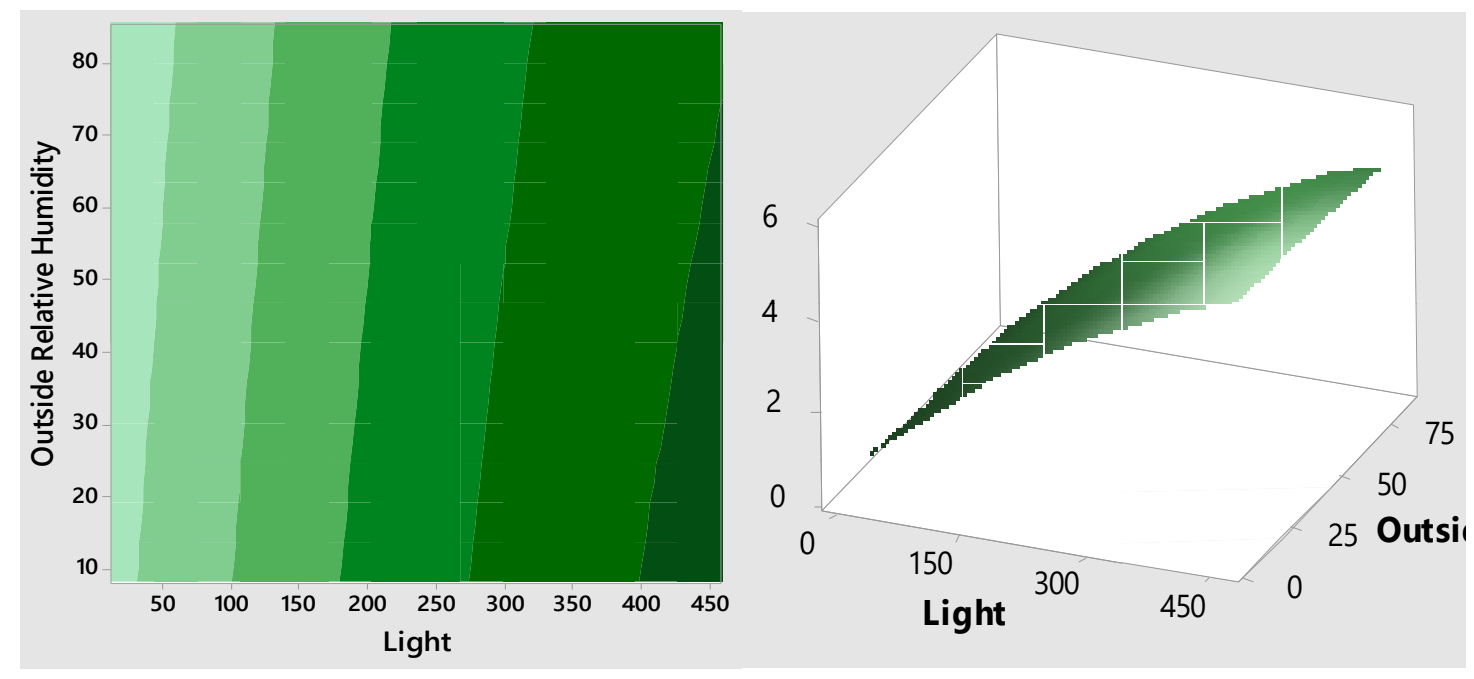

Figure 7 - Effect of Outside R.H., Illumination on Visual Comfort

\subsubsection{Effect of Outside Temperature, Illumination (light) on Visual}

\section{Comfort and Productivity}

Contour and surface plots in Figure 8 show that outside temperature does not significantly affect visual comfort. It confirms the ANOVA test result that outside temperature has no direct impact on indoor visual comfort. Illumination levels directly affect visual comfort, and the optimum range is $350-450$ Lux. 


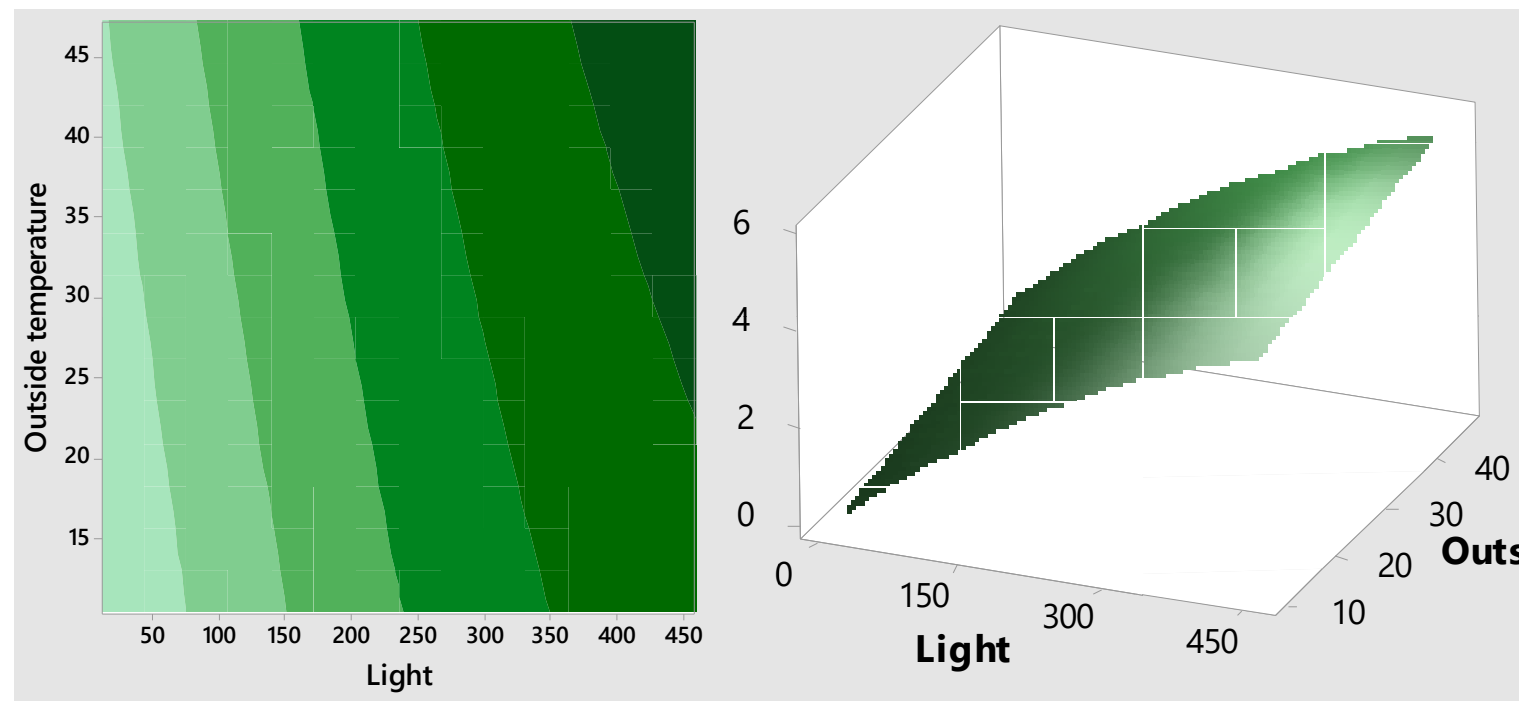

Figure 8 - Effect of Outside Temperature, lllumination on Visual Comfort

\subsubsection{Effect of Relative Humidity, Illumination (Light) on Visual Com- fort and Productivity}

The plots in Figure 9 show that relative humidity does not have a significant effect on visual comfort. However, ANOVA results show that relative humidity does affect visual comfort. It demonstrates that relative humidity has an indirect influence and no substantial impact compared to illumination (light intensity) on visual comfort. Illumination has a direct effect on visual comfort, and the optimum range is 325 - 450 Lux.

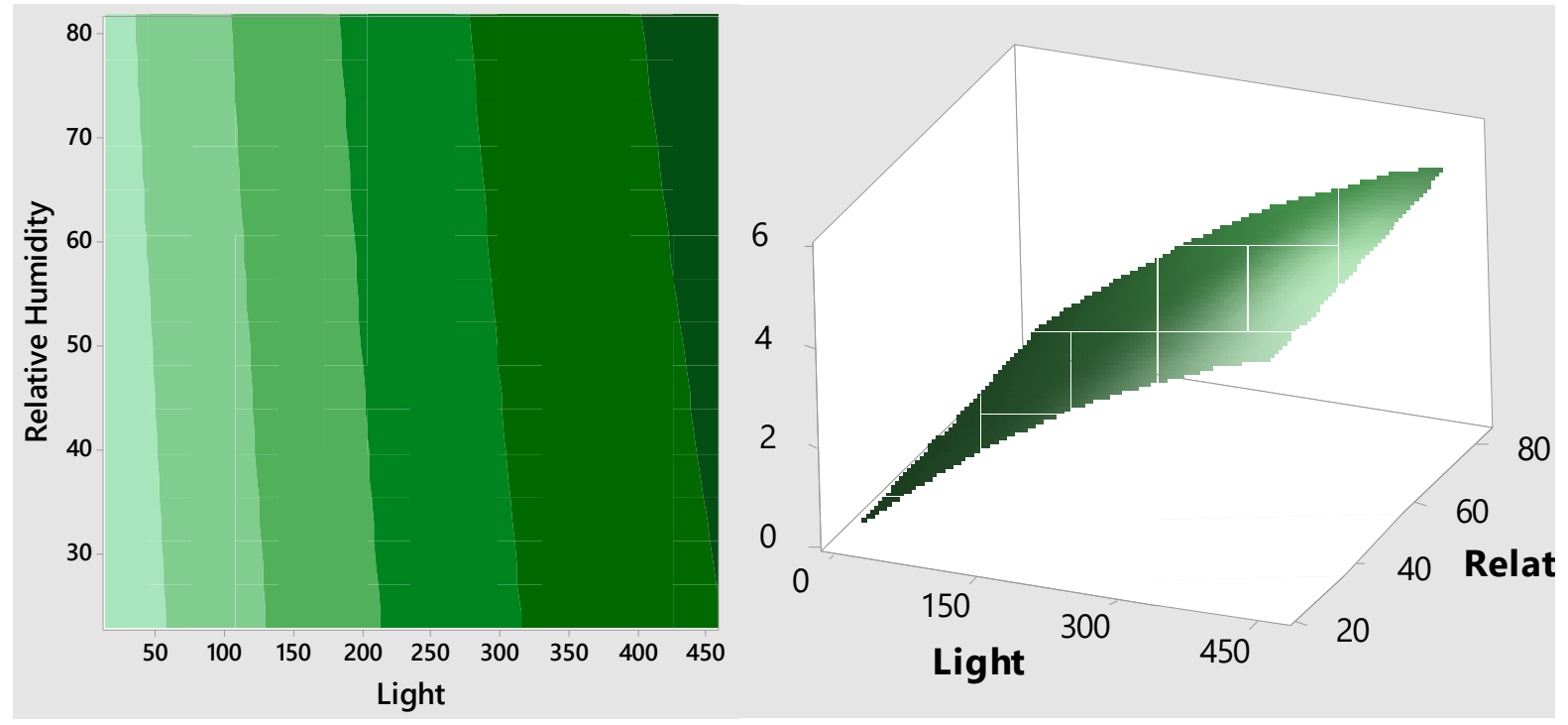

Figure 9 - Effect of Relative Humidity, Light on Visual Comfort 


\subsubsection{Effect of Temperature, Illumination (Light) on Visual Comfort and Productivity}

The contour and surface plots in figure 10 show that temperature does not significantly affect visual comfort compared to illumination. ANOVA test and relationship indicate that temperature does influence visual comfort. Illumination level directly affects visual comfort, and the optimum range is 325 - 450 Lux.

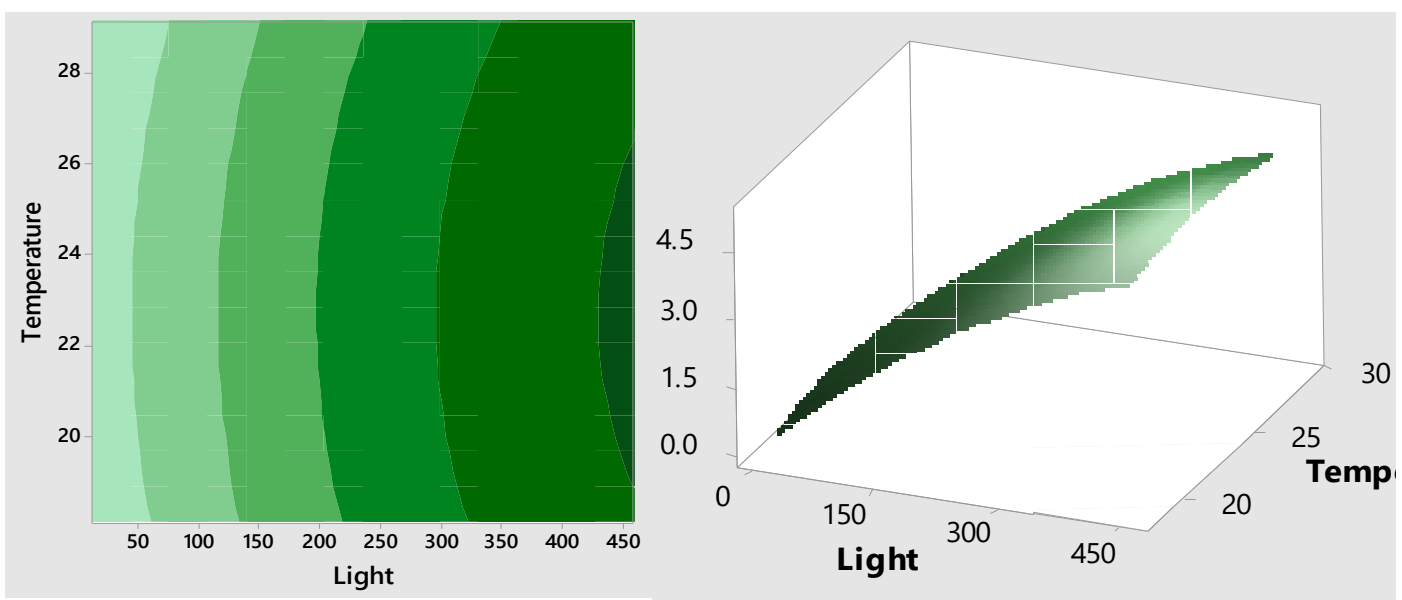

Figure 10 - Effect of Relative Humidity, Illumination (Light) on Visual Comfort

\section{Discussion}

This study aimed to outline the influence of various physical environmental parameters on occupants' visual comfort and productivity. Response surface analysis produced regression equation can determine occupant visual comfort in a similar geographic and climatic context. It also produced unique relationships between independent variables (indoor environmental quality parameters) and dependent variables (visual comfort and productivity). Table 4 indicates seven relationships were produced and examined from the response surface analysis.

\begin{tabular}{|c|c|c|c|c|}
\hline S.no. & $\begin{array}{c}\text { Independent } \\
\text { Variable 1 }\end{array}$ & $\begin{array}{c}\text { Effect \& } \\
\text { Range }\end{array}$ & $\begin{array}{c}\text { Independent } \\
\text { Variable 2 }\end{array}$ & Effect \& Range \\
\hline 1 & Temperature & $20-27^{\circ} \mathrm{C}$ & Carbon Dioxide & Up to $550 \mathrm{ppm}$ \\
\hline 2 & V.O.C. & No effect & Illumination & $350-540$ lux \\
\hline 3 & Sound & No effect & Illumination & 225 above positive \\
\hline
\end{tabular}




\begin{tabular}{|c|c|c|c|c|}
\hline S.no. & $\begin{array}{c}\text { Independent } \\
\text { Variable 1 }\end{array}$ & $\begin{array}{c}\text { Effect \& } \\
\text { Range }\end{array}$ & $\begin{array}{c}\text { Independent } \\
\text { Variable 2 }\end{array}$ & Effect \& Range \\
\hline 4 & $\begin{array}{c}\text { Outside Rela- } \\
\text { tive Humidity }\end{array}$ & No effect & Illumination & $275-450$ lux \\
\hline 5 & $\begin{array}{c}\text { Outside Tem- } \\
\text { perature }\end{array}$ & No effect & Illumination & $350-450$ lux \\
\hline 6 & $\begin{array}{c}\text { Relative Humid- } \\
\text { ity }\end{array}$ & No effect & Illumination & $325-450$ lux \\
\hline 7 & Temperature & No effect & Illumination & $325-450$ lux \\
\hline
\end{tabular}

Table 4 - Seven relationships between indoor environment quality factor and occupant productivity

The following sections discuss key findings of the indoor environmental parameters and their role in visual comfort and productivity and effect on building design and operations:

\subsection{Illumination}

Illumination has the maximum impact on occupant comfort and productivity. Results indicate that, comparatively, illumination has the most substantial influence over visual comfort and productivity than Temperature, V.O.C., Sound, Outside Relative Humidity, Outside Temperature, Relative Humidity and Temperature. Results indicate that illumination has a 'positive' effect from 225 lux and a 'very positive' impact from 325 till 450 lux. These results presented are focused on desktop work in an indoor environment. These findings confirm the current literature on illumination's effect on occupant visual comfort and productivity (Van Den Wymelenberg and Inanici, 2014; Lai et al., 2009; Han and Tai Kim, 2010). Beyond the literature confirmation, the study presents a new recommended lux range focusing on the productivity and mathematical relationship between illumination and productivity. The implications are that design professionals should concentrate on developing lighting design strategies that aim to establish ambient and task illumination levels.

Furthermore, this study outlined the recommended range for office tasks. It is also recommended to use both natural and artificial light to achieve the required illumination level, manage carbon footprint, and improve occupants' productivity. Literature has 
also highlighted that natural light is the preferred source of light for occupant wellbeing and productivity (Li and Tsang, 2008; Galasiu and Veitch, 2006; Shindler, 2019). Design automation with active façade elements is actively used along with passive design strategies to manage the daylight consumption in a well-lit building that promotes occupant visual comfort and productivity. Asset managers should manage the building's operational process to harvest maximum daylight by organising activities and spaces based on their illumination requirements.

\subsection{Temperature}

Results indicate that indoor temperature ranks second in the indoor environmental quality factor. The relationship shows that indoor temperature has a 'very positive' effect at $20-27^{\circ} \mathrm{C}$ and a neutral effect between $19-20^{\circ} \mathrm{C}$. The finding of an indirect effect of temperature on occupant visual comfort is a new contribution to the literature on indoor environmental quality and occupant productivity. However, the recommended range for visual comfort is the same as that for thermal comfort (Kaushik et al., 2020). It shows that thermal comfort has an indirect effect on visual comfort. Therefore, there shouldn't be significant design implications of this result for building design.

Nonetheless, building design professionals should follow thermal comfort guidelines. Design and operation professionals should focus on maintaining the recommended range using H.V.A.C. (Heating Ventilation and Air conditioning) system in mechanically ventilated buildings. In mix-mode buildings and natural ventilation, the focus should be more diverse, including passive design techniques such as building orientation, sun path, opening sizes and location, and plants and shrubs to manage the indoor thermal environment. It could be considered in the design and operation strategies and lighting design in the building's design phase. Lighting and the thermal environment influence each other, and both should be considered during the design phase using design and building simulation techniques.

\subsection{Relative Humidity}

ANOVA indicated that relative humidity influences occupant visual comfort and productivity. However, when compared to illumination, it showed minimal influence. It demonstrates that relative humidity has an indirect effect on visual comfort. It is a ther- 
mal comfort parameter, and as earlier indicated, the thermal environment has an indirect influence on occupant's visual comfort and productivity. Hence, relative humidity should be managed as per thermal comfort guidelines and should be kept in the comfort range to maintain thermal comfort.

\subsection{Sound}

ANOVA indicated that sound influences occupant visual comfort and productivity. However, compared to illumination, it showed no effect, indicating that sound doesn't have a more substantial impact than illuminance.

\subsection{Office Layout (Kind of Workspace, Wall Type)}

ANOVA indicated that both, kind of workspace and seat location near-wall type influences occupant comfort. This finding confirms that access to daylight positively influences visual comfort (Boyce, Peter, Hunter and Howlett, 2003; Li, 2010). It reinforces the importance of office layout, building orientation and façade design in the building design process (Lim et al., 2012; Yang and Nam, 2010; Yildirim, Akalin-Baskaya and Celebi, 2007; Mansfield, 2018).

\section{Conclusion}

This research study was conducted to outline the effect of the indoor environment on visual comfort and occupant productivity in office buildings. It used response surface methodology to present regression analysis and equation that represents the relationship between indoor environmental quality and occupant visual comfort and productivity. Results include seven relationships presented to show the effect of different indoor environmental quality parameters, their recommended range, and inferences. Findings indicate that occupants prefer illumination levels between 300 and 450 lux for the indoor working environment and shown preference towards daylight. This study recommends using passive and active design techniques to harvest natural light while managing the artificial light focus to maintain required lux levels. Apart from illumination levels, temperature, relative humidity, and access to daylight also influence visual comfort and productivity. These unique relationships also presented inter-relationships and dependencies. Based on this study, it is recommended that design guidelines and policies for office buildings should incorporate visual comfort and productivity in design 
criteria. These recommendations are only suggested for the Middle East region since the study was conducted in the Middle East.

These results have direct significance for building design. Construction professionals are to ensure that the design and specifications meet the recommended range of indoor environmental quality parameters during the building's operation phase. While this may lead to the higher energy usage of the building, annual operational efficiency gained from more productive and healthier occupants would lead to lower overall energy usage and production efficiency leading to lower costs. However, there is a need for future research on operational cost versus occupant productivity gain that can be sustained in the long run. The need for lighting design to be an essential part of the design process cannot be overemphasised enough. As a result, both daylight and artificial light should be used to achieve recommended levels of visual comfort in buildings. As this study has shown, utilising daylight can help to reduce the costs of enhancing the visual environment.

Furthermore, future research could also perform a comparative study of other building types other than office buildings and under different climatic conditions to see the nature of statistical relationships that may exist between occupant comfort, productivity, and indoor environmental quality parameters. Similarly, an A.I. Building Management system with an active façade system to harness maximum daylight by using sensors can be developed. This system will allow yearly data of sun and weather movements, along with lighting usage in the building. It can be further used to predict patterns of both daylight availability and usage of the buildings. It would help to improve the allocation of space in a building to minimise the carbon footprint of the building.

\section{References}

Abbaszadeh, S., Zagreus, L., Lehrer, D. and Huizenga, C. (2006) 'Occupant satisfaction with indoor environmental quality in green buildings', Center for the Built Environment, .

Al-Esia, Z. and Skok, W. (2015) 'Arab knowledge sharing in a multicultural workforce: a dual case study in the UAE', Arabian Journal of Business and Management Review, 2015. 
Alizadeh, M. and Sadrameli, S.M. (2019) 'Indoor thermal comfort assessment using PCM based storage system integrated with ceiling fan ventilation: Experimental design and response surface approach', Energy and Buildings, 188, pp. 297-313.

Allen, I.E. and Seaman, C.A. (2007) 'Likert scales and data analyses', Quality Progress, 40(7), pp. 64.

Aries, M.B.C. (2005) Human lighting demands: healthy lighting in an office environment. . Technische Universiteit Eindhoven. Available at: (Accessed: .

ASHRAE (1993) 'ASHRAE Fundamentals - Handbook', Atlanta, .

Bernstein, J.A., Alexis, N., Bacchus, H., Bernstein, I.L., Fritz, P., Horner, E., Li, N., Mason, S., Nel, A., Oullette, J., Reijula, K., Reponen, T., Seltzer, J., Smith, A. and Tarlo, S.M. (2008) 'The health effects of nonindustrial indoor air pollution', Journal of Allergy and Clinical Immunology, 121(3), pp. 585-591. doi: https://doi.org/10.1016/j.jaci.2007.10.045.

Beute, F. and de Kort, Y.,A.W. (2018) 'The natural context of wellbeing: Ecological momentary assessment of the influence of nature and daylight on affect and stress for individuals with depression levels varying from none to clinical', Health \& place, 49, pp. 7-18.

Bluyssen, P.M., De Oliveira Fernandes, E., Groes, L., Clausen, G., Fanger, P.O., Valbjørn, O., Bernhard, C.A. and Roulet, C.A. (1996) 'European Indoor Air Quality Audit Project in 56 Office Buildings', Indoor air, 6(4), pp. 221-238. doi: 10.1111/j.16000668.1996.00002.x.

Box, G.E.P. and Draper, N.R. (1987) Empirical model-building and response surfaces. Wiley New York.

Boyce, P.R. (1997) 'Light, sight and photobiology', Lighting Futures, 2(3).

Boyce, P., Hunter, C. and Howlett, O. (2003) 'The benefits of daylight through windows', Troy, New York: Rensselaer Polytechnic Institute, .

Bright, G.T. (2012) 'The economics of Biophilia', Why designing with nature in mind makes financial sense.New York (NY): Terrapin Bright Green, .

Bueno, A.M., de Paula Xavier, Antonio Augusto and Broday, E.E. (2021) 'Evaluating the Connection between Thermal Comfort and Productivity in Buildings: A Systematic Literature Review', Buildings, 11(6), pp. 244.

Butler, D.L. and Biner, P.M. (1989) 'Effects of setting on window preferences and factors associated with those preferences', Environment and Behavior, 21(1), pp. 17-31.

Caicedo, D. and Pandharipande, A. (2016) 'Daylight and occupancy adaptive lighting control system: An iterative optimisation approach', Lighting Research \& Technology, 48(6), pp. 661-675. 
Carletti, C., Cellai, G., Pierangioli, L., Sciurpi, F. and Secchi, S. (2017) 'The influence of daylighting in buildings with parameters nZEB: application to the case study for an office in Tuscany Mediterranean area', Energy Procedia, 140, pp. 339-350.

Chang, S. and Mahdavi, A. (2002) 'A hybrid system for daylight responsive lighting control', Journal of the Illuminating Engineering Society, 31(1), pp. 147-157.

CIBSE (2015) The CIBSE Journal CPD Programme: Lighting control technologies and strategies to cut energy consumption CIBSE.

Collinge, W.O., Landis, A.E., Jones, A.K., Schaefer, L.A. and Bilec, M.M. (2014) 'Productivity metrics in dynamic LCA for whole buildings: Using a post-occupancy evaluation of energy and indoor environmental quality tradeoffs', Building and Environment, 82, pp. 339-348. doi: 10.1016/j.buildenv.2014.08.032.

Cuttle, C. (1983) People and windows in workplaces. pp. 47.

David L.. DiLaura, Houser, K., Mistrick, R. and Gary R.. Steffy (2011) The Lighting Handbook: Reference and Application. Illuminating Engineering Society of North America.

de Vries, A., Souman, J.L., de Ruyter, B., Heynderickx, I. and de Kort, Y.A. (2018) 'Lighting up the office: The effect of wall luminance on room appraisal, office workers' performance, and subjective alertness', Building and Environment, 142, pp. 534-543.

Djongyang, N., Tchinda, R. and Njomo, D. (2010) 'Thermal comfort: A review paper', Renewable and Sustainable Energy Reviews, 14(9), pp. 2626-2640. doi: http://dx.doi.org/10.1016/j.rser.2010.07.040.

Doulos, L., Tsangrassoulis, A. and Topalis, F.V. (2005) A critical review of simulation techniques for daylight responsive systems.

Elzeyadi, I.M.K. (2011) 'Daylighting-Bias and Biophilia: Quantifying the Impact of Daylighting on Occupants Health', US Green Building Council.http://www.usgbc.org/sites/default/files/OR10 Daylighting\% 20Bias\% 20and\% 20Biophilia.pdf, .

Fisk, W.J., Spengler, J.D., Samet, J.M. and McCarthy, J.F. (1999) Indoor Air Quality Handbook.

Fisk, W.J. (2011) 'Potential nationwide improvements in productivity and health from better indoor environments', Lawrence Berkeley National Laboratory, .

Fisk, W.J. (2000a) 'Estimates of potential nationwide productivity and health benefits from better indoor environments: an update', Indoor air quality handbook, 4.

Fisk, W.J. (2000b) 'Health and productivity gains from better indoor environments and their relationship with building energy efficiency', Annual Review of Energy and the Environment, 25(1), pp. 537-566. 
Fontoynont, M. (2014) Daylight performance of buildings. Routledge.

Frontczak, M. and Wargocki, P. (2011) 'Literature survey on how different factors influence human comfort in indoor environments', Building and Environment, 46(4), pp. 922-937.

Galasiu, A.D. and Veitch, J.A. (2006) 'Occupant preferences and satisfaction with the luminous environment and control systems in daylit offices: a literature review', Energy and Buildings, 38(7), pp. 728-742.

Geng, Y., Ji, W., Lin, B. and Zhu, Y. (2017) 'The impact of thermal environment on occupant IEQ perception and productivity', Building and Environment, 121, pp. 158167.

Giarma, C., Tsikaloudaki, K. and Aravantinos, D. (2017) 'Daylighting and visual comfort in buildings' environmental performance assessment tools: a critical review', Procedia Environmental Sciences, 38, pp. 522-529.

Göçer, Ö, Candido, C., Thomas, L. and Göçer, K. (2019) 'Differences in occupants' satisfaction and perceived productivity in high-and low-performance offices', Buildings, 9(9), pp. 199.

Göçer, Ö, Hua, Y. and Göçer, K. (2015) 'Completing the missing link in building design process: Enhancing post-occupancy evaluation method for effective feedback for building performance', Building and Environment, 89, pp. 14-27. doi: 10.1016/j.buildenv.2015.02.011.

Gou, Z. and Lau, S.S. (2013) 'Post-occupancy evaluation of the thermal environment in a green building', Facilities, 31(7), pp. 357-371. doi: 10.1108/02632771311317493.

Gou, Z., Lau, S.S. and Ye, H. (2014) 'Visual alliesthesia: The gap between comfortable and stimulating illuminance settings', Building and Environment, 82, pp. 42-49. doi: 10.1016/j.buildenv.2014.08.001.

Grinde, B. and Patil, G.G. (2009) 'Biophilia: does visual contact with nature impact on health and wellbeing?', International Journal of Environmental Research and Public Health, 6(9), pp. 2332-2343.

Guzowski, M. (2000) Daylighting for sustainable design. McGraw-Hill Professional Publishing.

Hailu, H., Gelan, E. and Girma, Y. (2021) 'Indoor Thermal Comfort Analysis: A Case Study of Modern and Traditional Buildings in Hot-Arid Climatic Region of Ethiopia', Urban Science, 5(3), pp. 53.

Hamedani, Z., Solgi, E., Skates, H., Hine, T., Fernando, R., Lyons, J. and Dupre, K. (2019) 'Visual discomfort and glare assessment in office environments: A review of light-induced physiological and perceptual responses', Building and Environment, 153, pp. 267-280. 
Han, H. and Tai Kim, J. (2010) 'Application of high-density daylight for indoor illumination', Energy, 35(6), pp. 2654-2666. doi: 10.1016/j.energy.2009.05.037.

Hassanain, M.A. (2007) 'Post-occupancy indoor environmental quality evaluation of student housing facilities', Architectural Engineering and Design Management, 3(4), pp. 249-256.

Hill, W.J. and Hunter, W.G. (1966) 'A review of response surface methodology: a literature survey', Technometrics, 8(4), pp. 571-590.

Hirning, M.B., Isoardi, G.L., Coyne, S., Garcia Hansen, V.R. and Cowling, I. (2013) 'Post occupancy evaluations relating to discomfort glare: A study of green buildings in Brisbane', Building and Environment, 59, pp. 349-357. doi: 10.1016/j.buildenv.2012.08.032.

Hopkinson, R.G., Petherbridge, P. and Longmore, J. (1966) Daylighting. Heinemann.

Hua, Y., Oswald, A. and Yang, X. (2011) 'Effectiveness of daylighting design and occupant visual satisfaction in a LEED Gold laboratory building', Building and Environment, 46(1), pp. 54-64. doi: 10.1016/j.buildenv.2010.06.016.

Humphreys, M.A. (2005) 'Quantifying occupant comfort: are combined indices of the indoor environment practicable?', Building Research \& Information, 33(4), pp. 317325. doi: 10.1080/09613210500161950.

Humphreys, M.A. and Nicol, J.F. (2000) 'Outdoor temperature and indoor thermal comfort: Raising the precision of the relationship for the 1998 ASHRAE database of field studies/Discussion', ASHRAE Transactions, 106, pp. 485.

Kaushik, A., Arif, M., Tumula, P. and Ebohon, O.J. (2020) 'Effect of thermal comfort on occupant productivity in office buildings: response surface analysis', Building and Environment, 180, pp. 107021.

Kent, M. and Schiavon, S. (2020) 'Evaluation of the effect of landscape distance seen in window views on visual satisfaction', Building and Environment, 183, pp. 107160.

Kirk, R.E. (2012) 'Experimental design', Handbook of Psychology, Second Edition, 2.

Kittler, R., Hayman, S., Ruck, N. and Julian, W. (1992) 'Daylight measurement data: Methods of evaluation and representation', Lighting Research \& Technology, 24(4), pp. 173-187.

Knoop, M., Stefani, O., Bueno, B., Matusiak, B., Hobday, R., Wirz-Justice, A., Martiny, K., Kantermann, T., Aarts, M. and Zemmouri, N. (2020) 'Daylight: What makes the difference?', Lighting Research \& Technology, 52(3), pp. 423-442.

Kong, Z., Utzinger, D.M., Freihoefer, K. and Steege, T. (2018) 'The impact of interior design on visual discomfort reduction: a field study integrating lighting environments with POE survey', Building and Environment, 138, pp. 135-148. 
Lai, A.C.K., Mui, K.W., Wong, L.T. and Law, L.Y. (2009) 'An evaluation model for indoor environmental quality (IEQ) acceptance in residential buildings', Energy and Buildings, 41(9), pp. 930-936. doi: http://dx.doi.org/10.1016/j.enbuild.2009.03.016.

Li, D.H.W. (2010) 'A review of daylight illuminance determinations and energy implications', Applied Energy, 87(7), pp. 2109-2118.

Li, D.H.W. and Lam, J.C. (2001) 'Evaluation of lighting performance in office buildings with daylighting controls', Energy and Buildings, 33(8), pp. 793-803. doi: http://dx.doi.org/10.1016/S0378-7788(01)00067-6.

Li, D.H.W. and Tsang, E.K.W. (2008) 'An analysis of daylighting performance for office buildings in Hong Kong', Building and Environment, 43(9), pp. 1446-1458. doi: http://dx.doi.org/10.1016/j.buildenv.2007.07.002.

Lim, Y., Kandar, M.Z., Ahmad, M.H., Ossen, D.R. and Abdullah, A.M. (2012) 'Building façade design for daylighting quality in typical government office building', Building and Environment, 57, pp. 194-204. doi: http://dx.doi.org/10.1016/j.buildenv.2012.04.015.

Lin, Z. and Deng, S. (2008) 'A study on the thermal comfort in sleeping environments in the subtropics-Developing a thermal comfort model for sleeping environments', Building and Environment, 43(1), pp. 70-81. doi: http://dx.doi.org/10.1016/j.buildenv.2006.11.026.

Lipczynska, A., Schiavon, S. and Graham, L.T. (2018) 'Thermal comfort and self-reported productivity in an office with ceiling fans in the tropics', Building and Environment, 135, pp. 202-212.

Lottrup, L., Stigsdotter, U.K., Meilby, H. and Claudi, A.G. (2015) 'The workplace window view: a determinant of office workers' work ability and job satisfaction', Landscape Research, 40(1), pp. 57-75.

Manning, M.A. (2006) 'An Experimental Evaluation and Comparison of Four Daylighting Strategies for Schools in North Carolina', .

Mansfield, K.P. (2018) 'Architectural lighting design: A research review over 50 years', Lighting Research \& Technology, 50(1), pp. 80-97.

Mawson, A. (2002) 'The workplace and its impact on productivity', Advanced Workplace Associates, London, .

Mujan, I., Anđelković, A.S., Munćan, V., Kljajić, M. and Ružić, D. (2019) 'Influence of indoor environmental quality on human health and productivity-A review', Journal of Cleaner Production, 217, pp. 646-657.

Myers, R.H., Montgomery, D.C. and Anderson-Cook, C.M. (2016) Response surface methodology: process and product optimisation using designed experiments. John Wiley \& Sons. 
Nagy, E., Yasunaga, S. and Kose, S. (1995) 'Japanese office employees' psychological reactions to their underground and above-ground offices', Journal of Environmental Psychology, 15(2), pp. 123-134.

Ne'Eman, E. and Hopkinson, R.G. (1970) 'Critical minimum acceptable window size: a study of window design and provision of a view', Lighting Research \& Technology, 2(1), pp. 17-27.

Nicol, J.F. and Humphreys, M.A. (2002) 'Adaptive thermal comfort and sustainable thermal standards for buildings', Energy and Buildings, 34(6), pp. 563-572.

Omer, A.M. (2008) 'Energy, environment and sustainable development', Renewable and Sustainable Energy Reviews, 12(9), pp. 2265-2300. doi: 10.1016/j.rser.2007.05.001.

Osibona, O., Solomon, B.D. and Fecht, D. (2021) 'Lighting in the Home and Health: A Systematic Review', International journal of environmental research and public health, 18(2), pp. 609.

Peretti, C. and Schiavon, S. (2011) 'Indoor environmental quality surveys. A brief literature review', .

Rea, M.S., Figueiro, M.G. and Bullough, J.D. (2002) 'Circadian photobiology: An emerging framework for lighting practice and research', Lighting Research and Technology, 34(3), pp. 177-187.

Rea, M.S. (2000) 'The IESNA lighting handbook: reference \& application', .

Reinhart, C.F., Mardaljevic, J. and Rogers, Z. (2006) 'Dynamic daylight performance metrics for sustainable building design', Leukos, 3(1), pp. 7-31.

Romm, J. and Browning, W. (1994) Greening the Building and the Bottom Line - Increasing productivity through energy-efficient design. Rocky Mountain Institute. Available at:(Accessed: .

Rubin, A.I., Collins, B.L. and Tibbott, R.L. (1978) 'Window blinds as potential energy saver-a case study, NBS Building Science Series, vol. 112', National Institute for Standards and Technology, Gaithersburg, MA, USA, .

Shindler, R. (2019) 'Investing in Better Outcomes: The Impact of Daylight in the Built Environment', .

Słomiński, S. and Krupiński, R. (2018) 'Luminance distribution projection method for reducing glare and solving object-floodlighting certification problems', Building and Environment, 134, pp. 87-101.

Steffy, G. (2002) Architectural lighting design. John Wiley \& Sons.

Stein, B., Reynolds, J.S. and McGuinness, W.J. (1992) Mechanical and electrical equipment for buildings. J. Wiley \& Sons. 
Tabachnick, B.G. and Fidell, L.S. (2007) Experimental designs using ANOVA. Thomson/Brooks/Cole Belmont, CA.

Turan, I., Chegut, A., Fink, D. and Reinhart, C. (2020) 'The value of daylight in office spaces', Building and Environment, 168, pp. 106503.

Van Den Wymelenberg, K. and Inanici, M. (2014) 'A critical investigation of common lighting design metrics for predicting human visual comfort in offices with daylight', Leukos, 10(3), pp. 145-164.

Wong, L., Caddick, Z., Kuriyagawa, Y. and Flynn-Evans, E. (2017) 'The Effects of Primary Light Sources on Worker Performance and Alertness', .

Wotton, E. (1982) An investigation of the effects of windows and lighting in offices. Health and Welfare Canada.

Ximénez, M.C. and San Martín, R. (2000) 'Application of response surface methodology to the study of person-organisation fit', Psicothema, 12(1), pp. 151-158.

Yang, I. and Nam, E. (2010) 'Economic analysis of the daylight-linked lighting control system in office buildings', Solar Energy, 84(8), pp. 1513-1525. doi: 10.1016/j.solener.2010.05.014.

Yildirim, K., Akalin-Baskaya, A. and Celebi, M. (2007) 'The effects of window proximity, partition height, and gender on perceptions of open-plan offices', Journal of Environmental Psychology, 27(2), pp. 154-165. doi: http://dx.doi.org/10.1016/j.jenvp.2007.01.004.

Yun, G.Y., Kong, H.J., Kim, H. and Kim, J.T. (2012) 'A field survey of visual comfort and lighting energy consumption in open plan offices', Energy and Buildings, 46, pp. 146-151. 